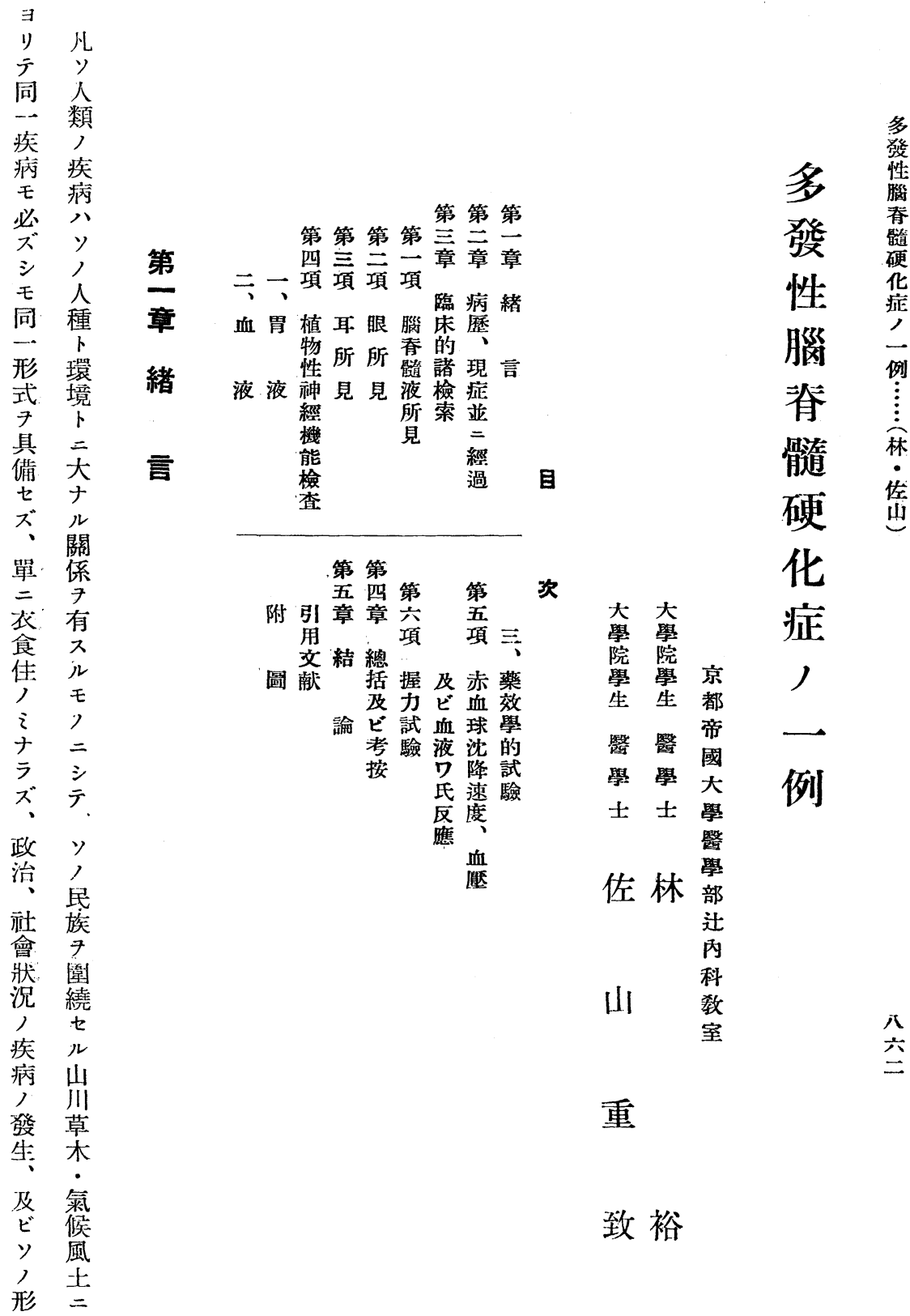




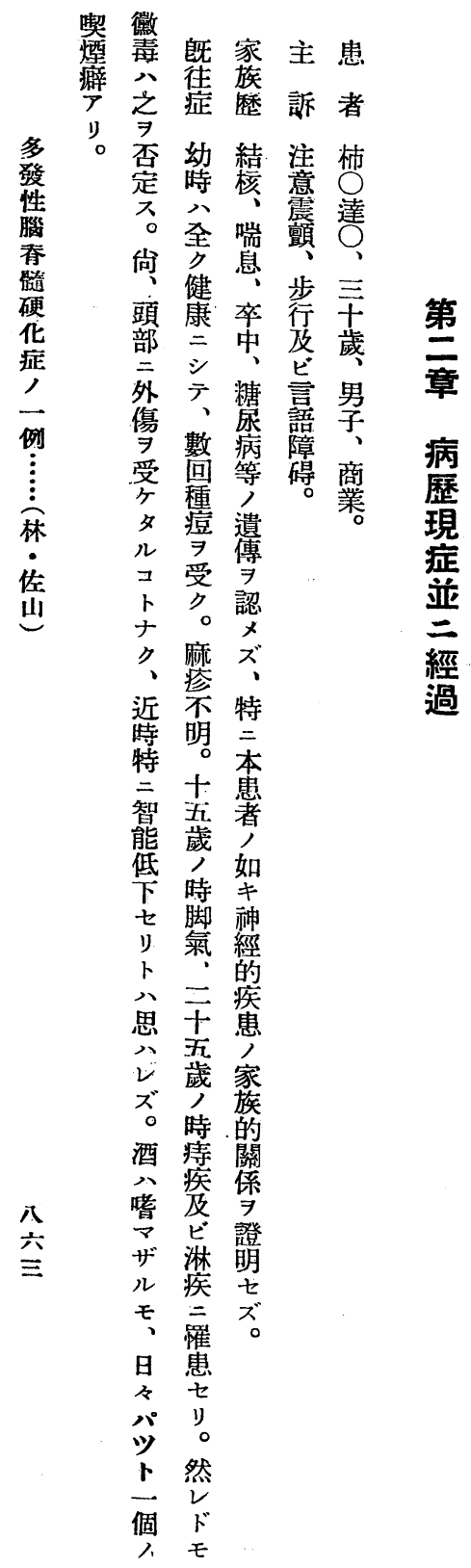

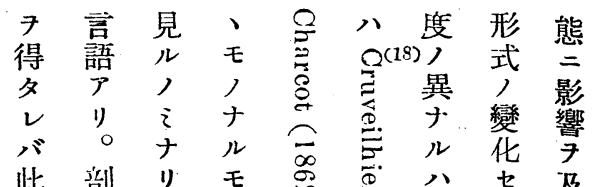

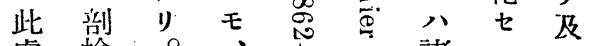
處檢。门口諸ルボ 二上本本 $\infty \underset{\infty}{\infty}$ 種 $八$ 報、拝邦总舀疾古了 告硬分二门病來卜 七化比 $\bar{\infty}=\underbrace{}_{\infty}$ 二 知 ン性較 八至兴於 ラ 有 卜病的其り ス篯若例 多年 谌正記 數者名層載認事キ 散二少精二厶實事 發來り、細始ルナ䐝 的 二、僅ル、、。 全瀶力記 載 即テ

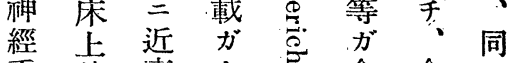

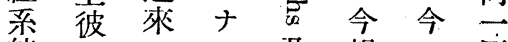
統人二サ及報日國 二 $八 \nu$ ビ告歐网 發导、夕、只米二 生务 小(21)!。門少諸テ

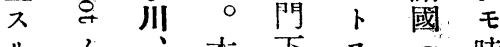
ル, 本下 7 所大(22)佂《於代 見謂容八总多分 ル三、歐 名發ル變 ○. 對 長(19)米志性卜遷 最症澤二品惱 本二 近、污答邦俳 余即加(12)八 慢 䯕 等 ₹ 藤 慢 导硬 於 汁意辻(33)中 ガ化永病 內 震、樞 始二小,

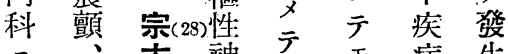

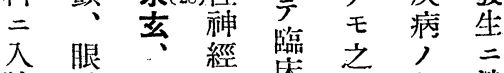
院球及經床 学種消 七震 ビ 患的見類長

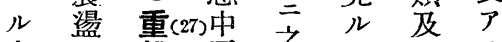

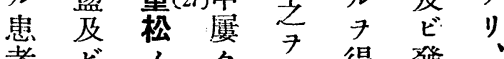
者ビ断名見診得發又

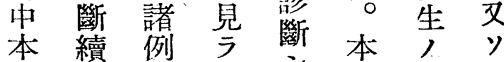
姃性 $九$ 症頻, 


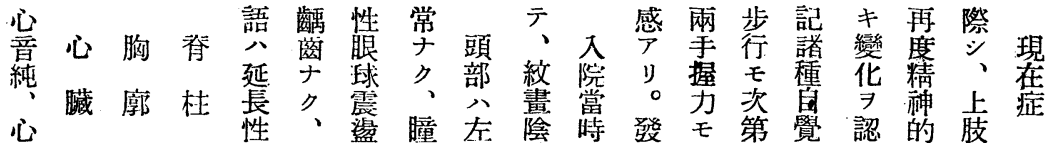

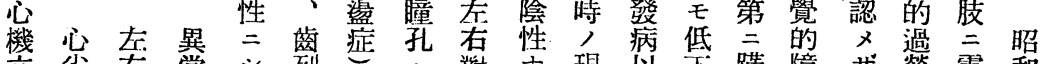

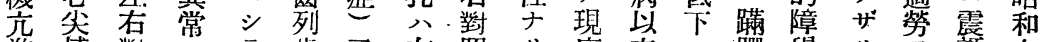

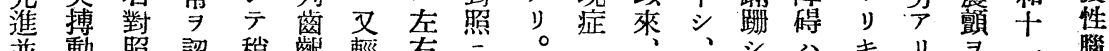

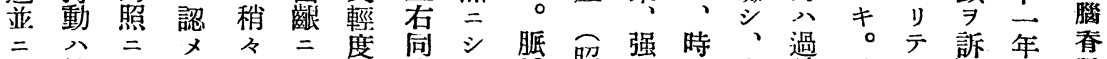

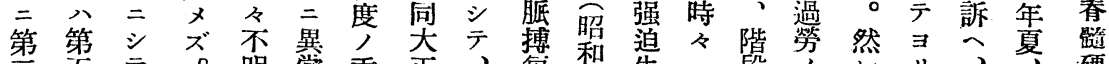

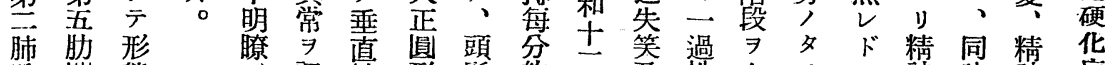

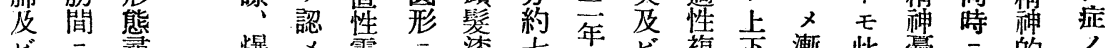

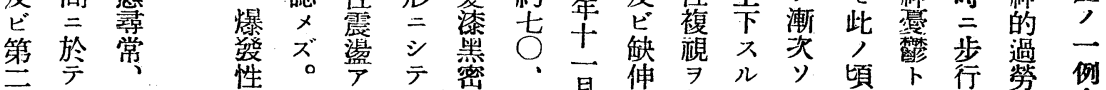
大左呼 性 咽 動乳吸帶喉 $ト$ 對

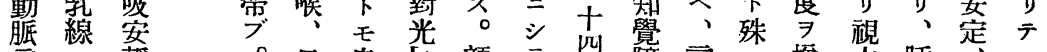
云 $\exists$ 静

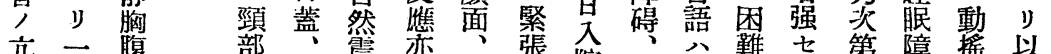

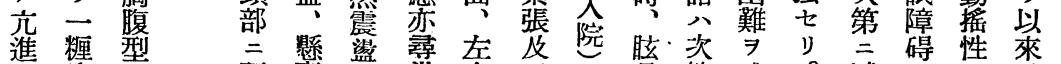

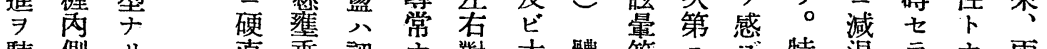

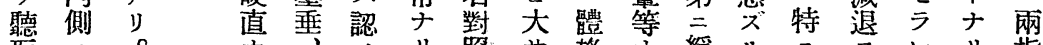

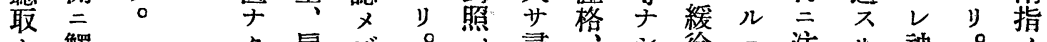
七 觸 ズ 知

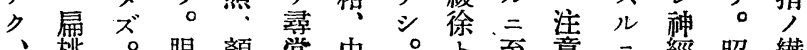

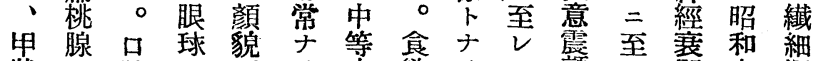

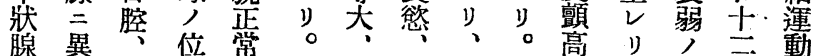

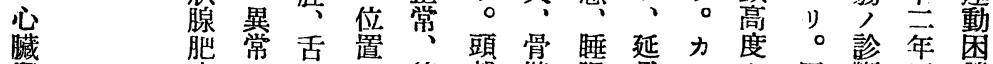

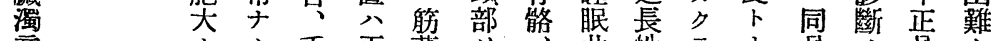
竞

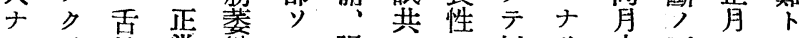

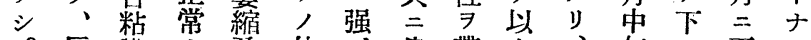
八。反膜ナ犮他、良帶占、旬三至レ 右 左

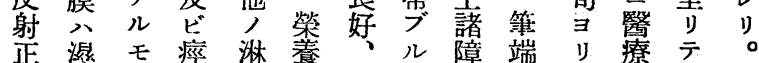

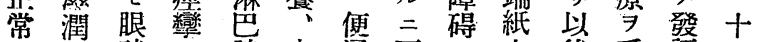
胸 テ

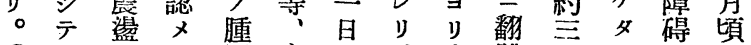
活淡父ズ脹皮一。除跳ケレタヨ 上.

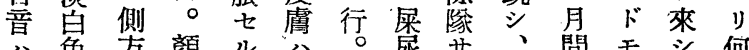
八色方顏几公。尿サ、間至シ何八

四 拙, 注面モ緊失ル䇝入以、等

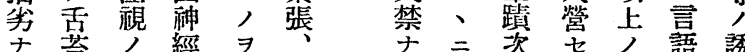

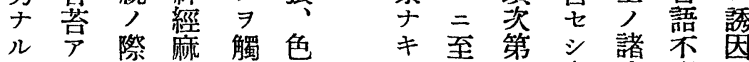

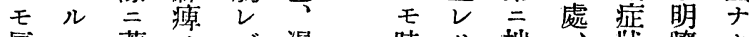

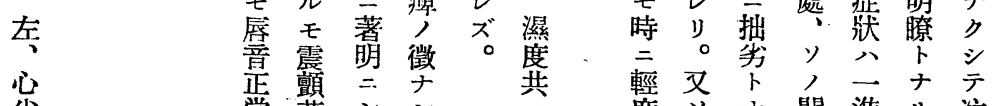
尖常萎 シ シ。言度り,ナ間進ル。漼 致

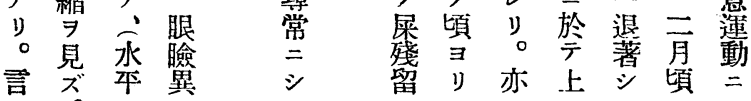
菻 


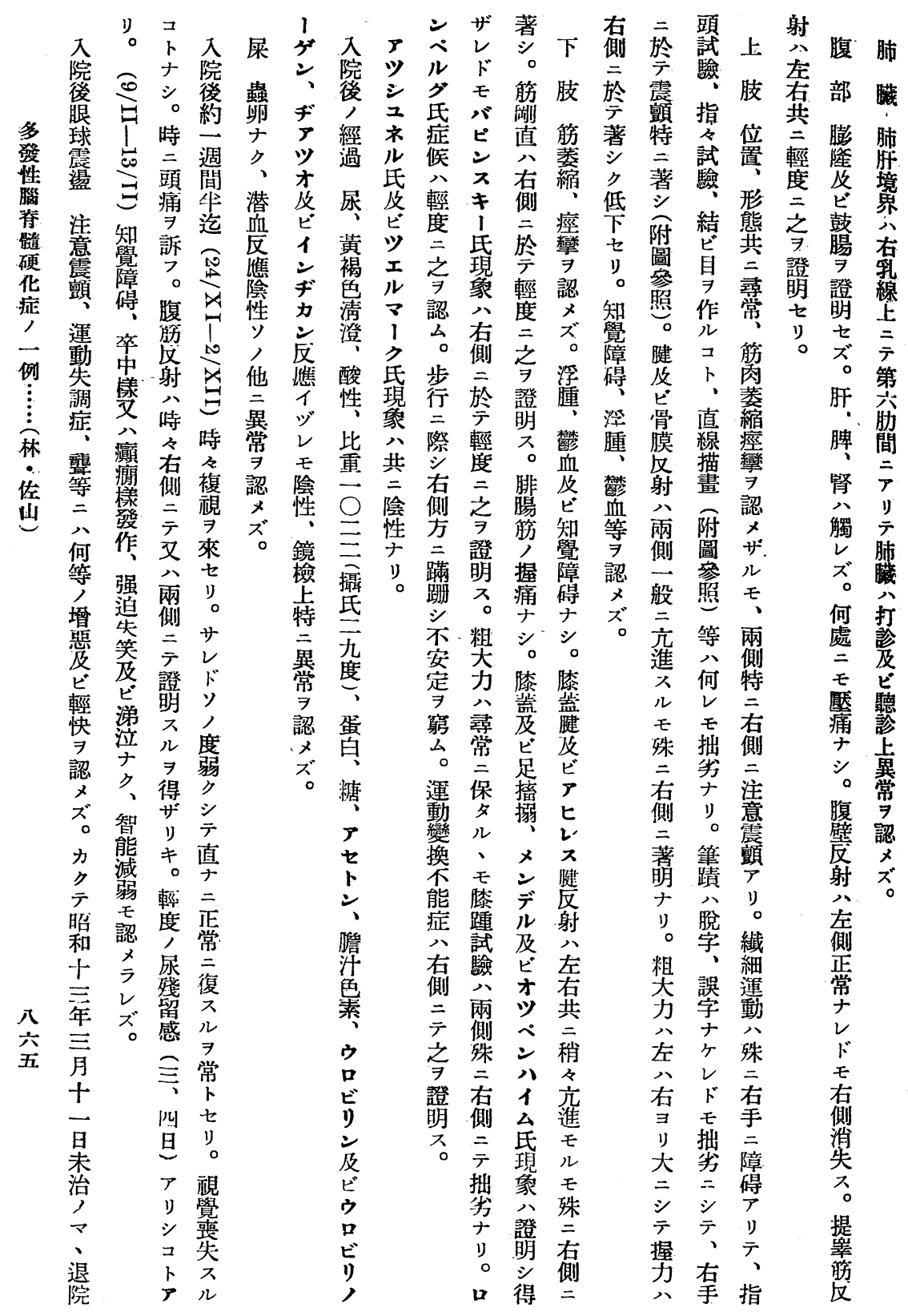



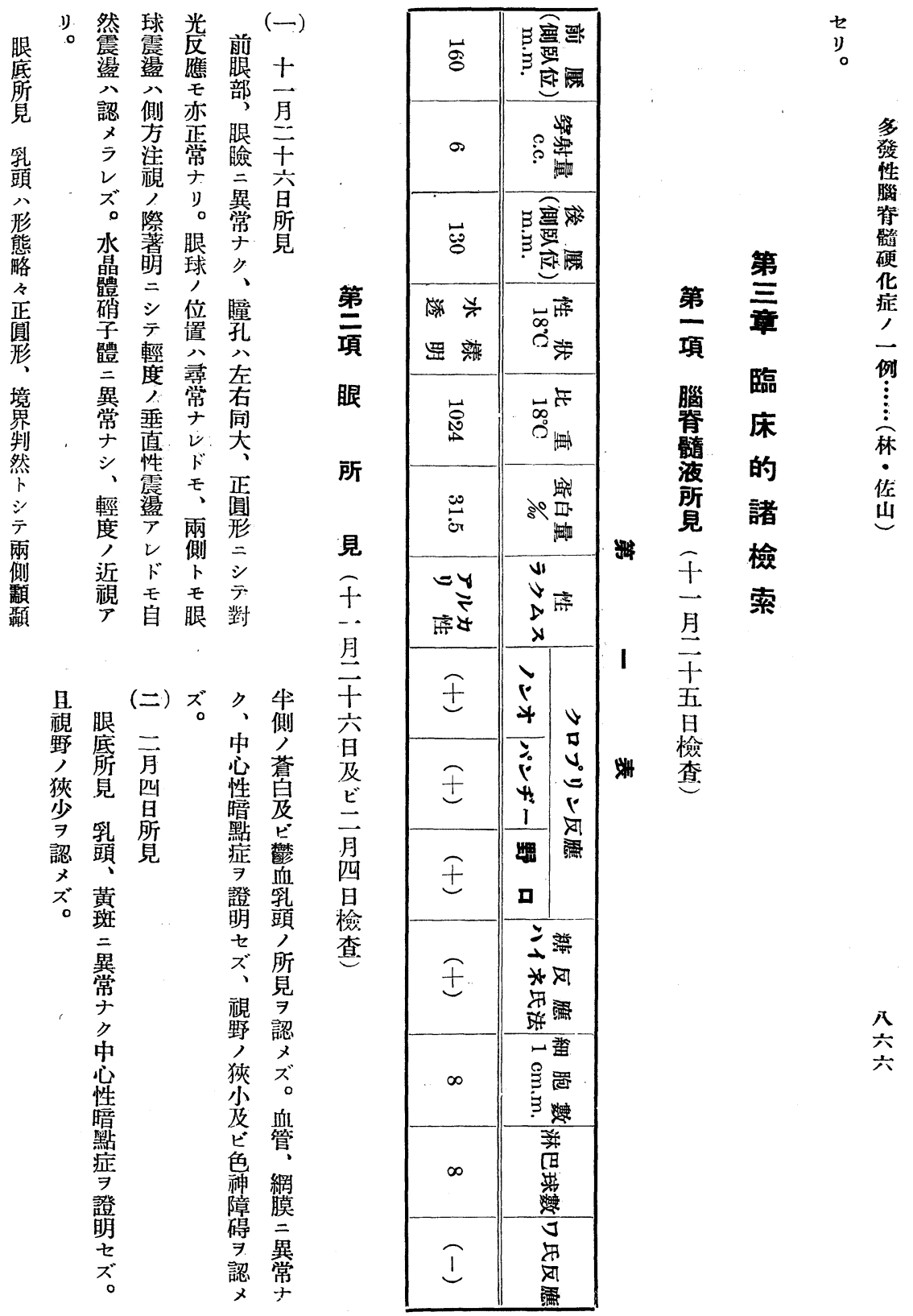


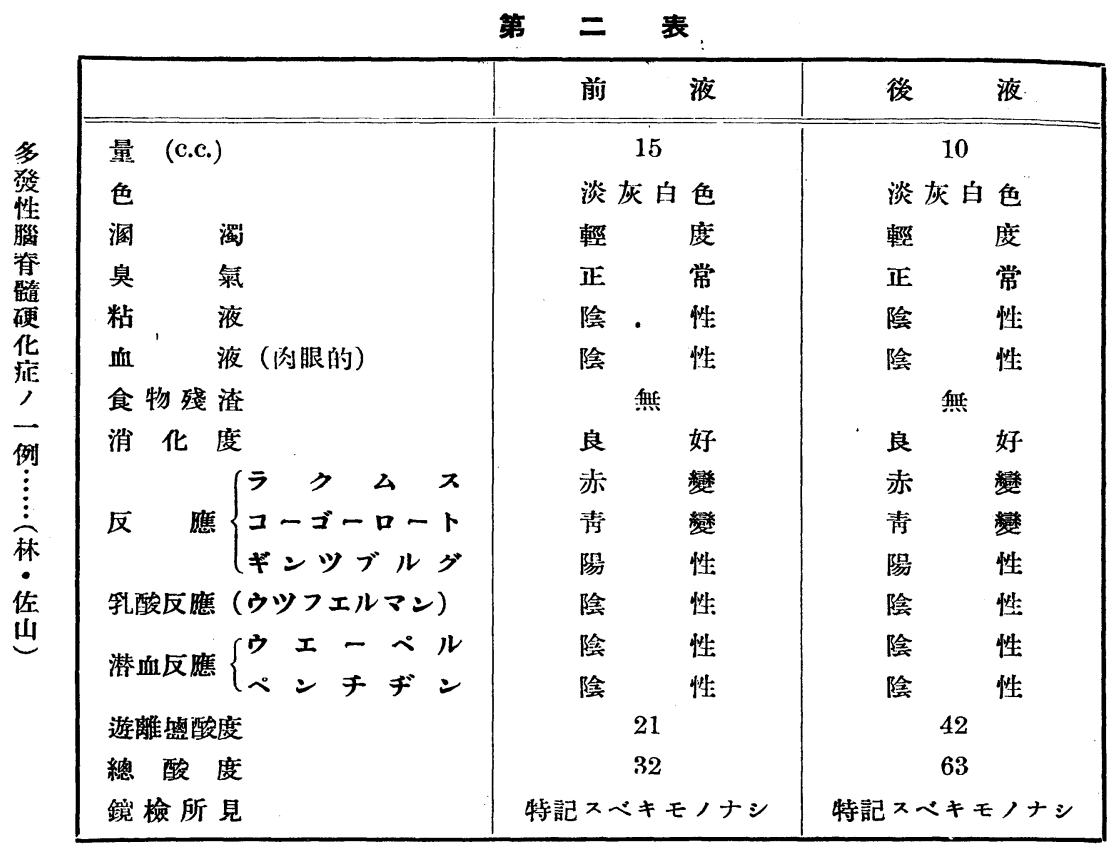

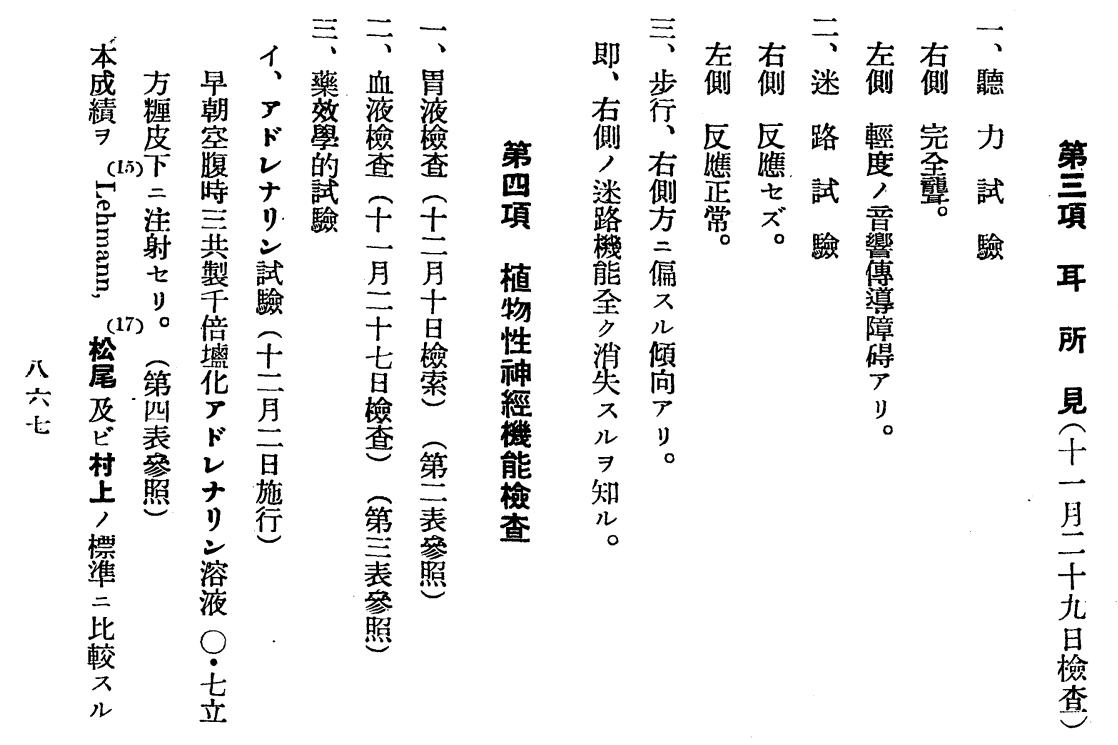




\begin{tabular}{|c|c|c|c|}
\hline 赤 & 球 & 白 血 & 球 \\
\hline $\begin{array}{l}\text { 總 數 (1 c.m.m.) } \\
\text { ヘモグロビン含有量 } \\
\text { (ザーリー氏法) } \\
\text { 血色 素 㛊 數 }\end{array}$ & $\begin{array}{l}570 \times 10^{4} \\
108 \% \\
0.94\end{array}$ & $\begin{array}{l}\text { 總 數 (1 c.m.m.) } \\
\text { 中性多核白血球 }\left\{\begin{array}{l}\text { 桿 狀 核 } \\
\text { 分 葉 核 }\end{array}\right. \\
\text { エオジン嗜好白血球 } \\
\text { ・盐基 性 白 血 球 } \\
\text { 淋 巴 球 }\left\{\begin{array}{l}\text { 小 } \\
大\end{array}\right. \\
\text { 大單核及ビ移行型 }\end{array}$ & $\begin{array}{r}89 \times 10^{2} \\
16.4 \% \\
49.6 \% \\
0.4 \% \\
0.0 \% \\
22.0 \% \\
8.4 \% \\
3.2 \%\end{array}$ \\
\hline
\end{tabular}

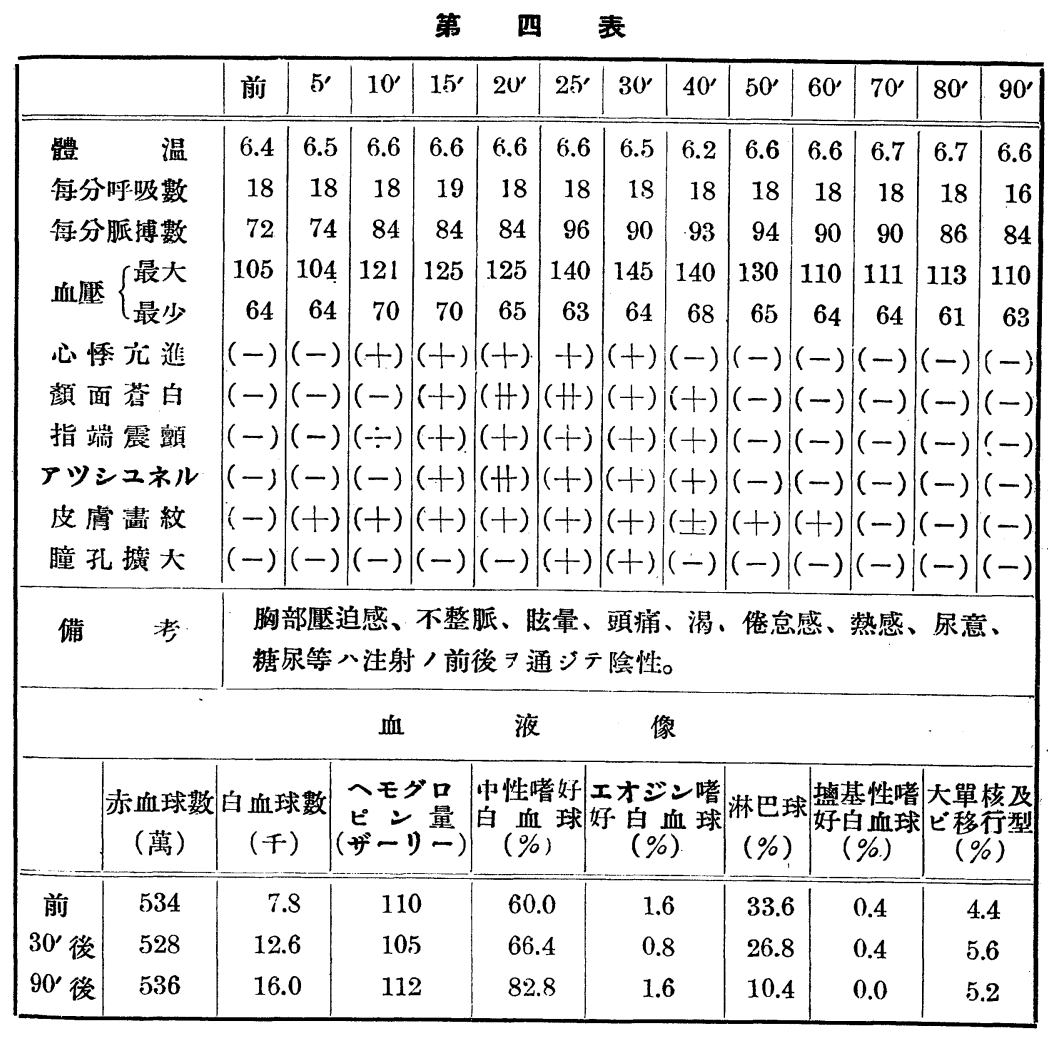


第 五 表

\begin{tabular}{|c|c|c|c|c|c|c|c|c|c|c|c|c|c|c|}
\hline & & 前 & $5^{\prime}$ & $10^{\prime}$ & $15^{\prime}$ & $20^{\prime}$ & $25^{\prime}$ & $30^{\prime}$ & $40^{\prime}$ & $50^{\prime}$ & $6 v^{\prime}$ & $70^{\prime}$ & $80^{\circ}$ & $90^{\prime}$ \\
\hline & 溫 & 6.0 & 6.4 & 6.4 & 6.4 & 6.3 & 6.3 & 6.3 & 6.2 & 6.3 & 6.4 & 6.0 & 6.5 & 9.2 \\
\hline 每分 & 呼吸數 & 18 & 18 & 18 & 16 & 18 & 17 & 18 & 18 & 18 & 18 & 18 & 18 & 18 \\
\hline 每分 & 脈搏數 & 60 & 72 & 68 & 72 & 72 & 72 & 68 & 64 & 67 & 64 & 63 & 63 & 68 \\
\hline 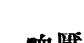 & 最大 & 111 & 112 & 113 & 113 & 113 & 115 & 113 & 112 & 112 & 111 & 111 & 112 & 113 \\
\hline & \{最少 & 67 & 51 & 48 & 49 & 50 & 55 & 57 & 57 & 61 & 64 & 65 & 64 & 66 \\
\hline & 感 & $(-)$ & $(-)$ & $+)$ & $i+1$ & $(+t)$ & $(++)$ & $(+)$ & $(+)$ & $(+)$ & $(-)$ & $(-) \mid$ & $(-)$ & $(-)$ \\
\hline 瞳 孔 & し 縮 少 & $(-i)$ & $(-)$ & $(-)$ & $(+)$ & $(+)$ & $(+)$ & $(+)$ & $(+)$ & $(\div)$ & $(-)$ & $(-)$ & $(-)$ & $(-)$ \\
\hline & 汗 & $(-)$ & $(-)$ & $(-)$ & $(\div)$ & $(+)$ & $(+)$ & $(t)$ & $(\div)$ & $(-)$ & $(-)$ & $(-)$ & $(-)$ & $(-)$ \\
\hline 頝 面 & 可 紅 潮 & $(-)$ & $(-)$ & $(\div)$ & $(+)$ & $(+)$ & $(+)$ & $(+)$ & $(\div)$ & $(-)$ & $(-)$ & $(-)$ & $(-)$ & $(-)$ \\
\hline 唾 & 液 量 & 0 & 2 & 0 & 5 & 7 & 12 & 12 & 12 & 15 & 12 & 8 & 5 & 2 \\
\hline & 㛈 & & is & 闪. & 7 & 亡進 & 耑震 & 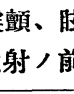 & 莗、 & 乎吸 & $\begin{array}{l}\text { 難。 } \\
\text { 陰| }\end{array}$ & 嗞 & $\therefore$ 流 & \\
\hline & . & & & 血 & & 液 & & & 像 & & & & & \\
\hline & $\begin{array}{c}\text { 赤血球數 } \\
\text { (萬) }\end{array}$ & $\begin{array}{r}\text { 白血纴 } \\
\text { (千 }\end{array}$ & & $\begin{array}{l}\text { 血色 } \\
\text { (サー }\end{array}$ & $\begin{array}{l}\text { 素量 } \\
\text { リー) }\end{array}$ & 中性 & $\begin{array}{l}\text { 嗜好 } \\
\text { 而球 } \\
\text { \%) }\end{array}$ & 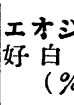 & $\begin{array}{l}\text { 㳣二搘 } \\
\text { 血 球 }\end{array}$ & 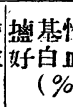 & $\begin{array}{l}\text { 性嗜 } \\
\text { 血球 } \\
\text { \%) }\end{array}$ & $\begin{array}{c}\text { 淋巴球 } \\
(\%)\end{array}$ & $\mid \begin{array}{l}\text { 救單 } \\
\text { ビ移 }\end{array}$ & $\begin{array}{l}\text { 果核及 } \\
\text { 行型 } \\
\text { \%) }\end{array}$ \\
\hline 前 & 531 & 6. & & 10 & & & 0.8 & & 1.2 & & 4 & 20.4 & & 7.2 \\
\hline $30^{\prime}$ 後 & 548 & 6. & & 10 & & & 5.6 & & 1.2 & & .0 & 28.4 & & 4.8 \\
\hline $90^{\prime}$ 後 & 548 & 6. & & 10 & & & 5.0 & & 0.8 & & .4 & 24.0 & & 8.8 \\
\hline
\end{tabular}

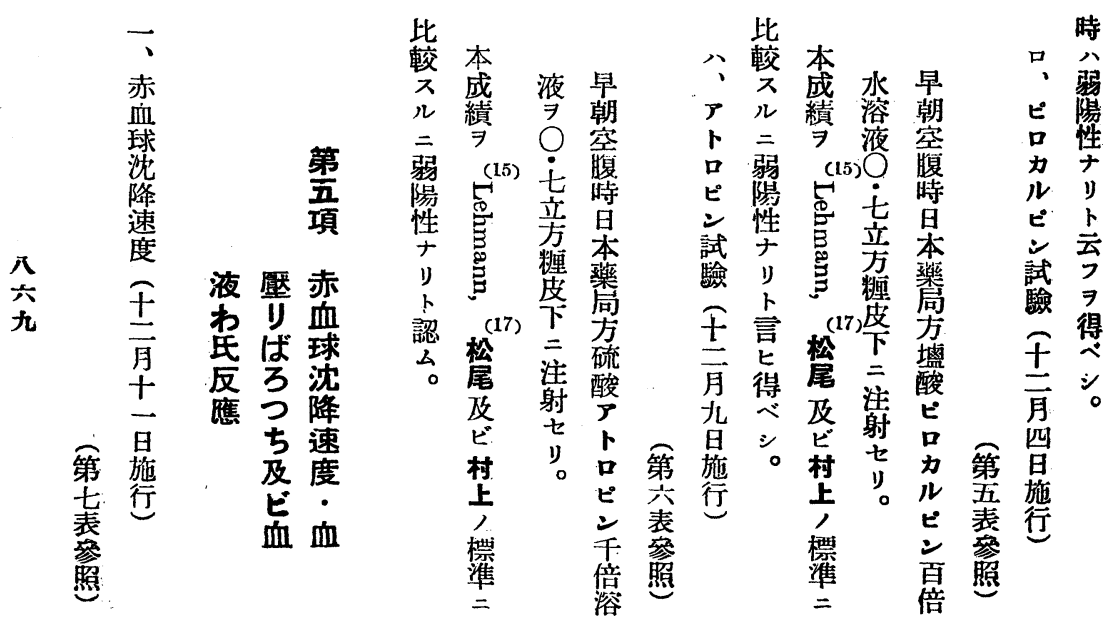


第 大狺

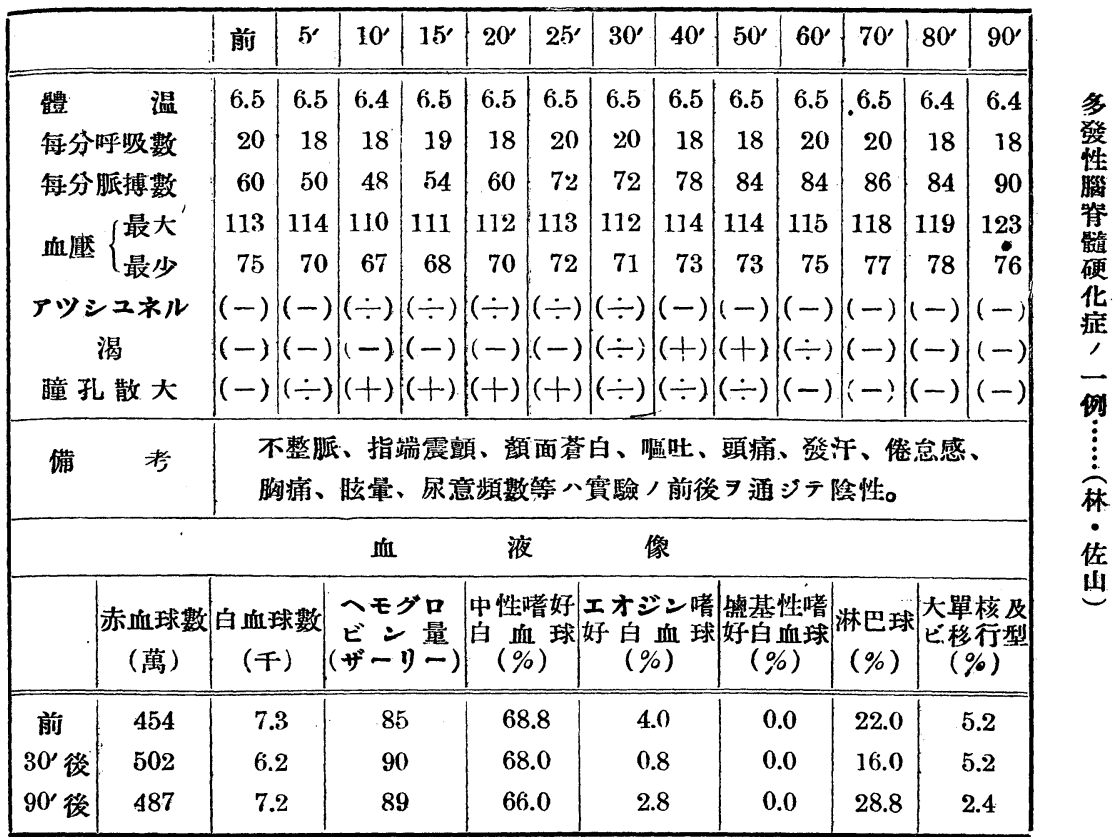

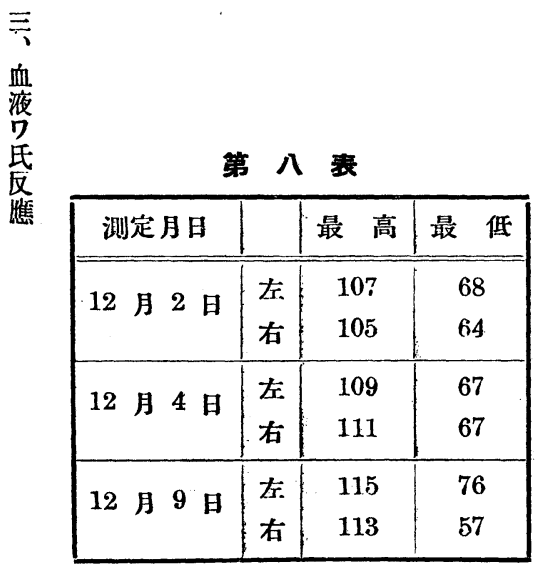

\begin{tabular}{|c|c|}
\hline \multicolumn{2}{|c|}{ 第七丧 } \\
\hline 經過時間 & 沈降速度 \\
\hline $15^{\prime}$ & 0.5 \\
\hline $30^{\prime}$ & 1 \\
\hline $1^{\circ}$ & 4 \\
\hline $2^{\circ}$ & 7 \\
\hline $3^{\circ}$ & 12 \\
\hline $6^{\circ}$ & 28 \\
\hline $12^{\circ}$ & 45 \\
\hline $24^{\circ}$ & 62 \\
\hline \multicolumn{2}{|c|}{ M. S. $R=3.8$} \\
\hline
\end{tabular}


反ン試二意テ複り

應ヂ驗 テ 震延視 ソ ズ及有革著性ビ, セ 多○ビ 侧二明・尿後 シ 發即野二之二不殘肉如 性于品テ示明留體り 梄右氏拙證亏嘹感的

春側反劣明筋爆 7 過本

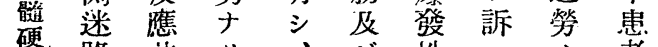
化路汜り、当性へ, 者

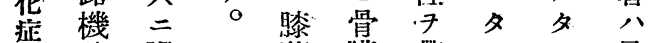
芷能陽口篮膜帶りメ 最 一全性ン腱反只。上初 例ク、へ及射夕入肢心 消蛋几 ビ モ り院り身 并失白分亦。當注過 休 ス 量氏七右腹時意勞

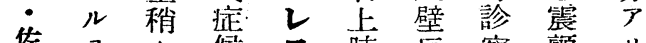

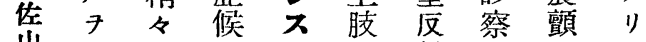
山涊增 輕腱二射七及每 ×扣度反充八シ 夕陽射進消二步手 リ。 性少不失腿行,

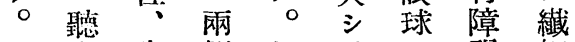
又打步側粗、二碍 細 爻、行 特大提八, 運 下左二二力辠水度動 レ側際右及反本 $丹$ 障 チ八シ 側 ビ 射性 增 碍 リ夏、二握八及加サ ン響右テ方左ビセレ

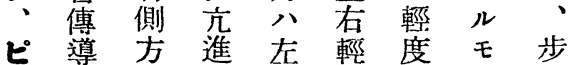
口障二 カ碍蹒。右二垂ナ及

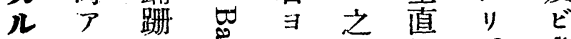
ピリス 号り 性○發 ン・。总大證震向語 八ビ側脊八りり拝患碍

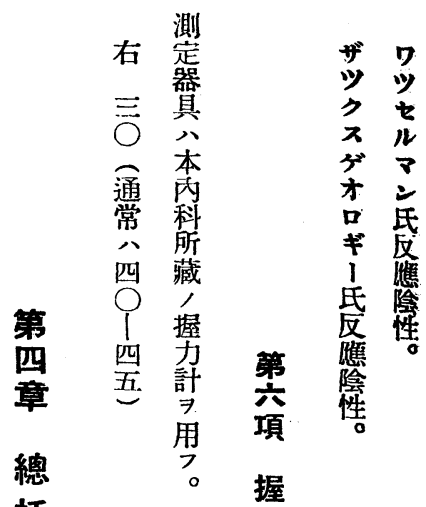
括 力 按<smiles>[H][R]([H])=[W]</smiles>

七ア 八䯕右○リア者 小完夜 側下。少來 口全所三肢上發 三

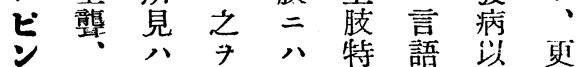
反迷、證筋二八棑二 應路ノ明㴊右舌時襄

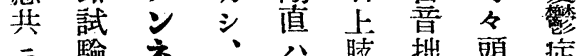
二驗 米公肢拙頭证 弱 


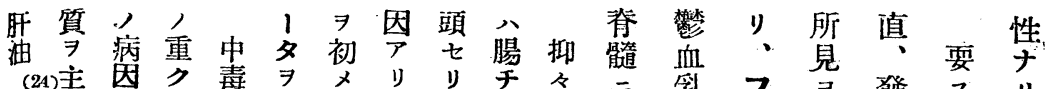

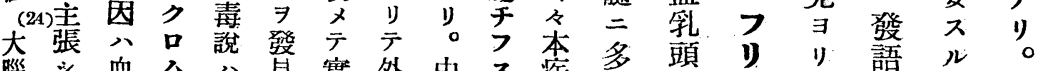

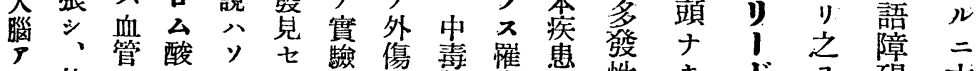

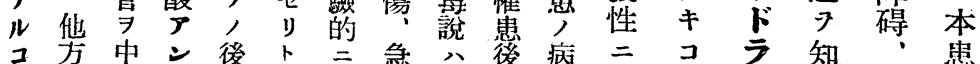

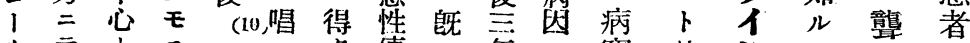

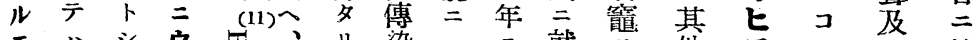
エ、シウ

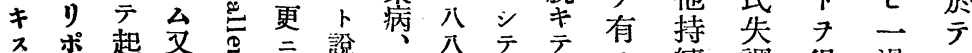

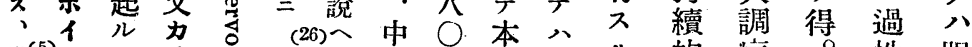

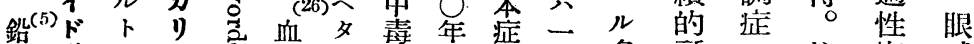

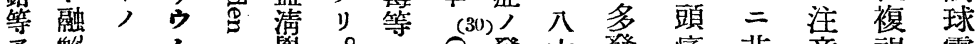

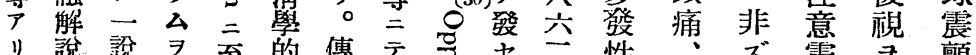

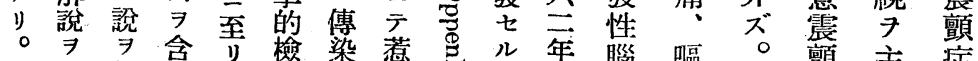

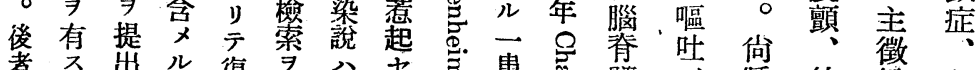

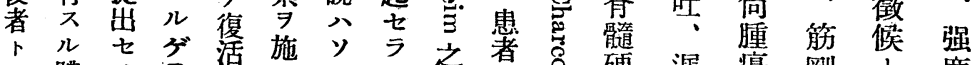

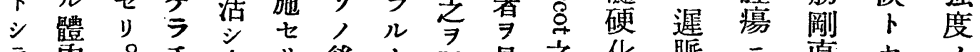
テ离。千來り後卜説見之化脈二直七,

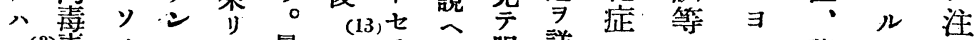

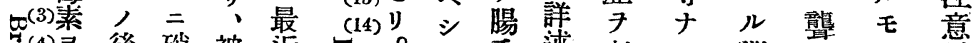

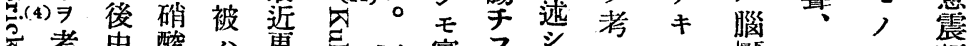

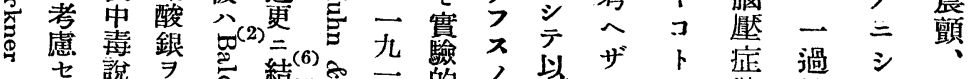

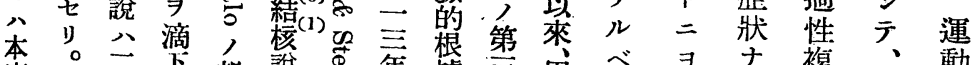

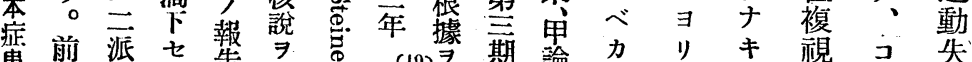

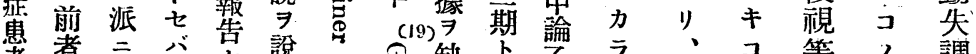

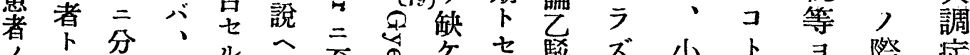
血 シ 、同ル 至至

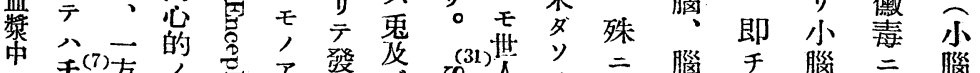

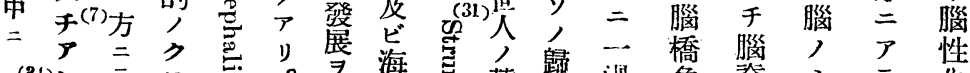

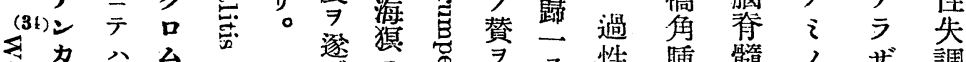

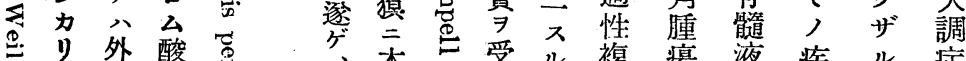

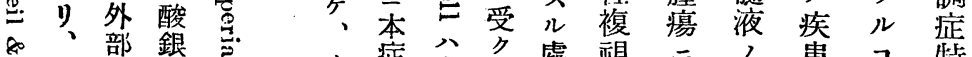

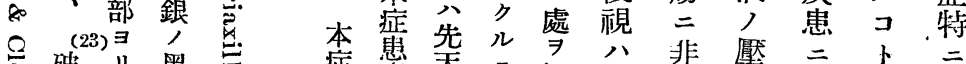

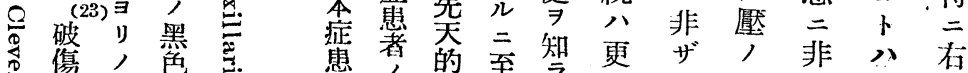

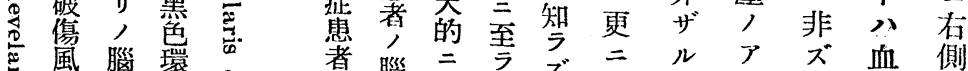

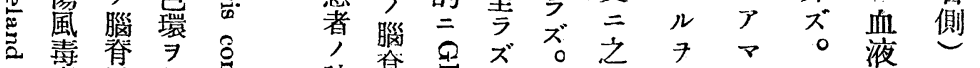

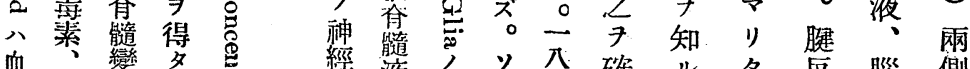

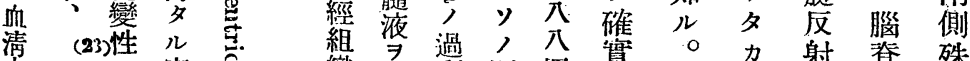
中- $\rightarrow$ 實 各稚 萊

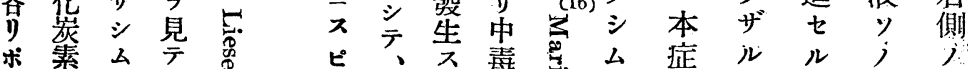

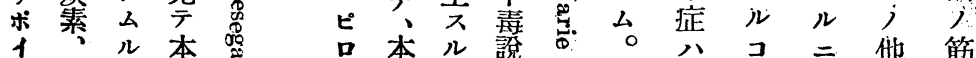

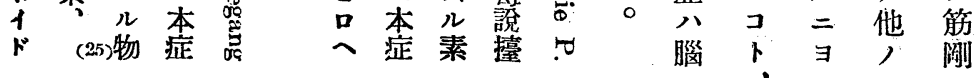




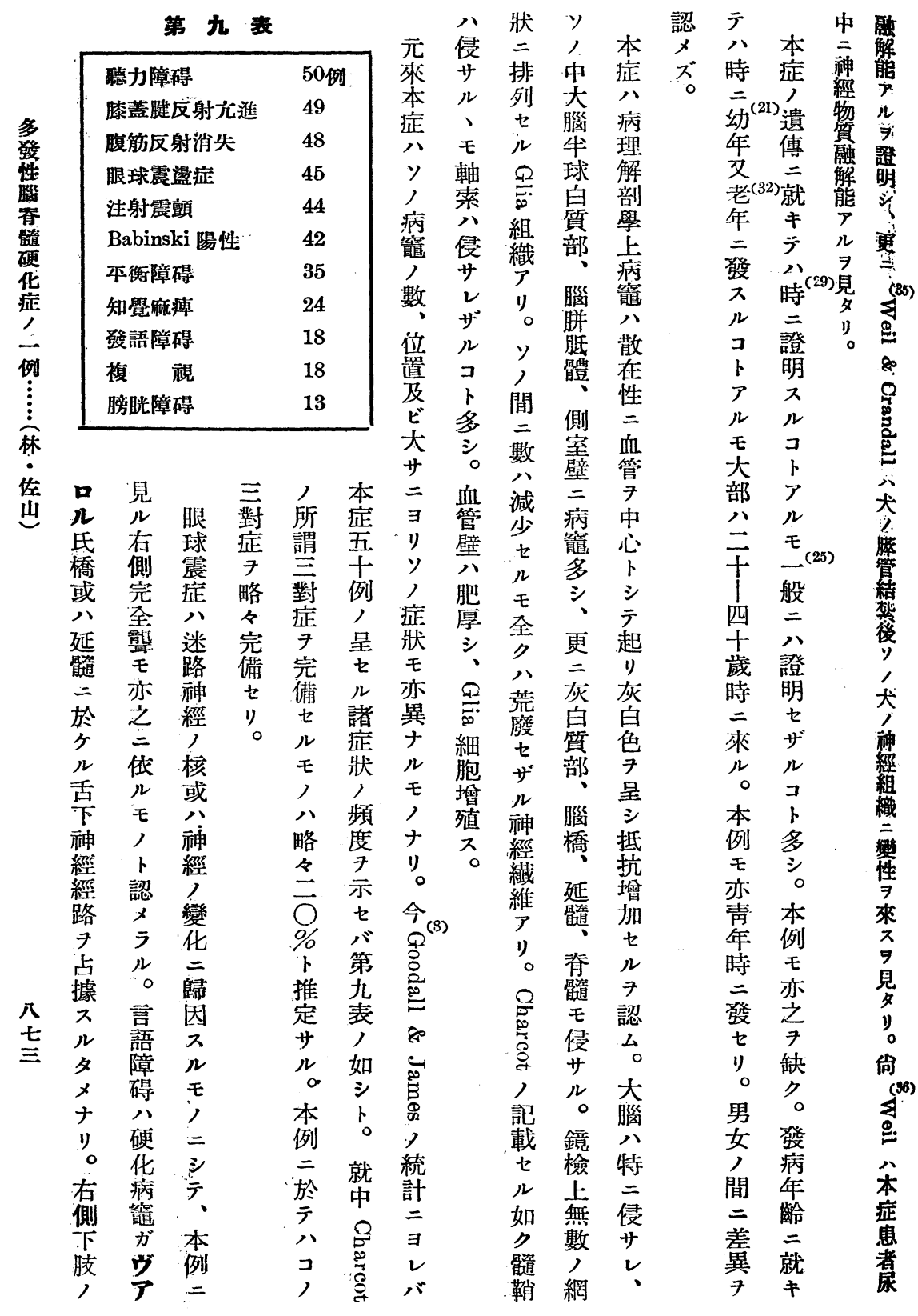




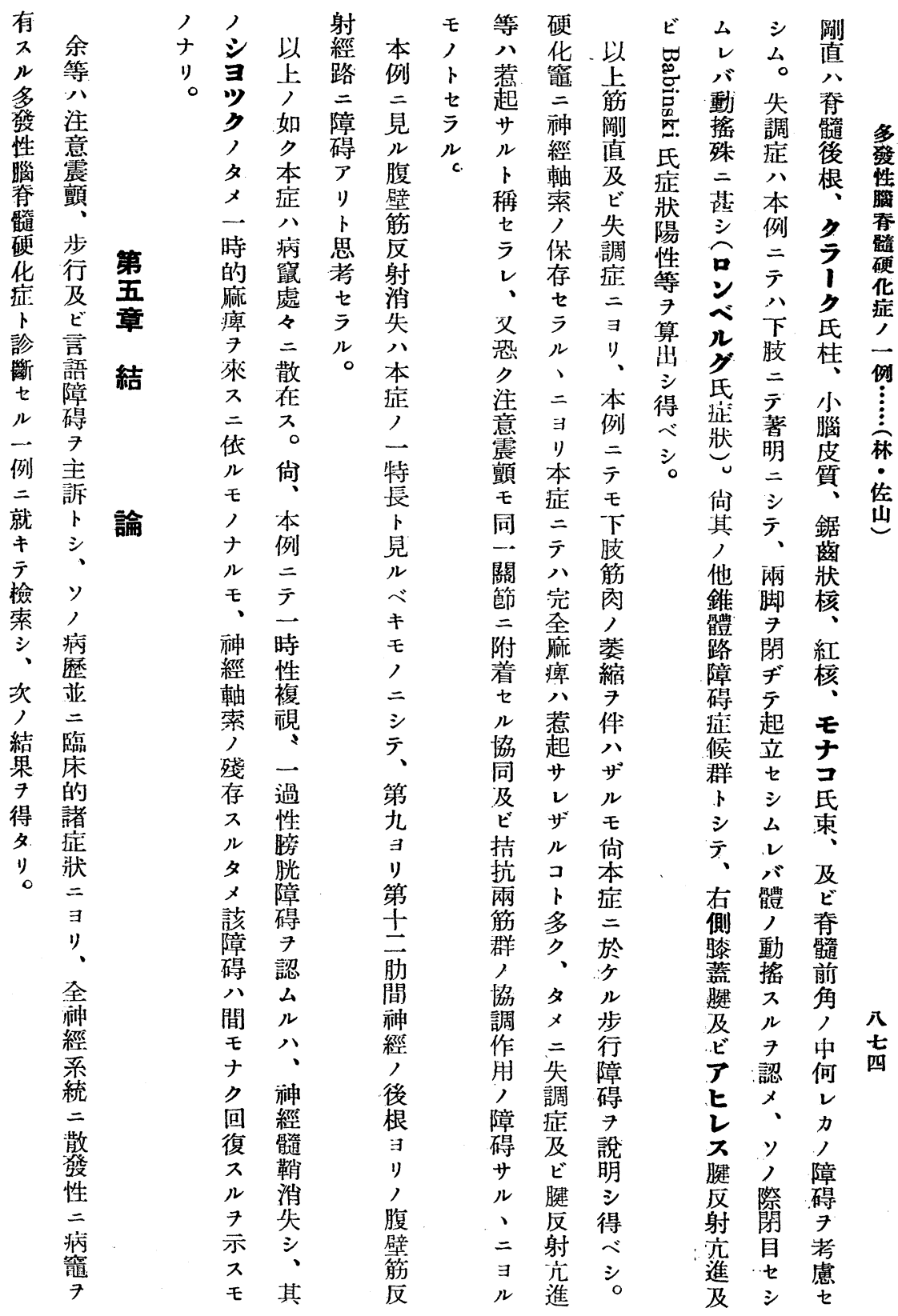




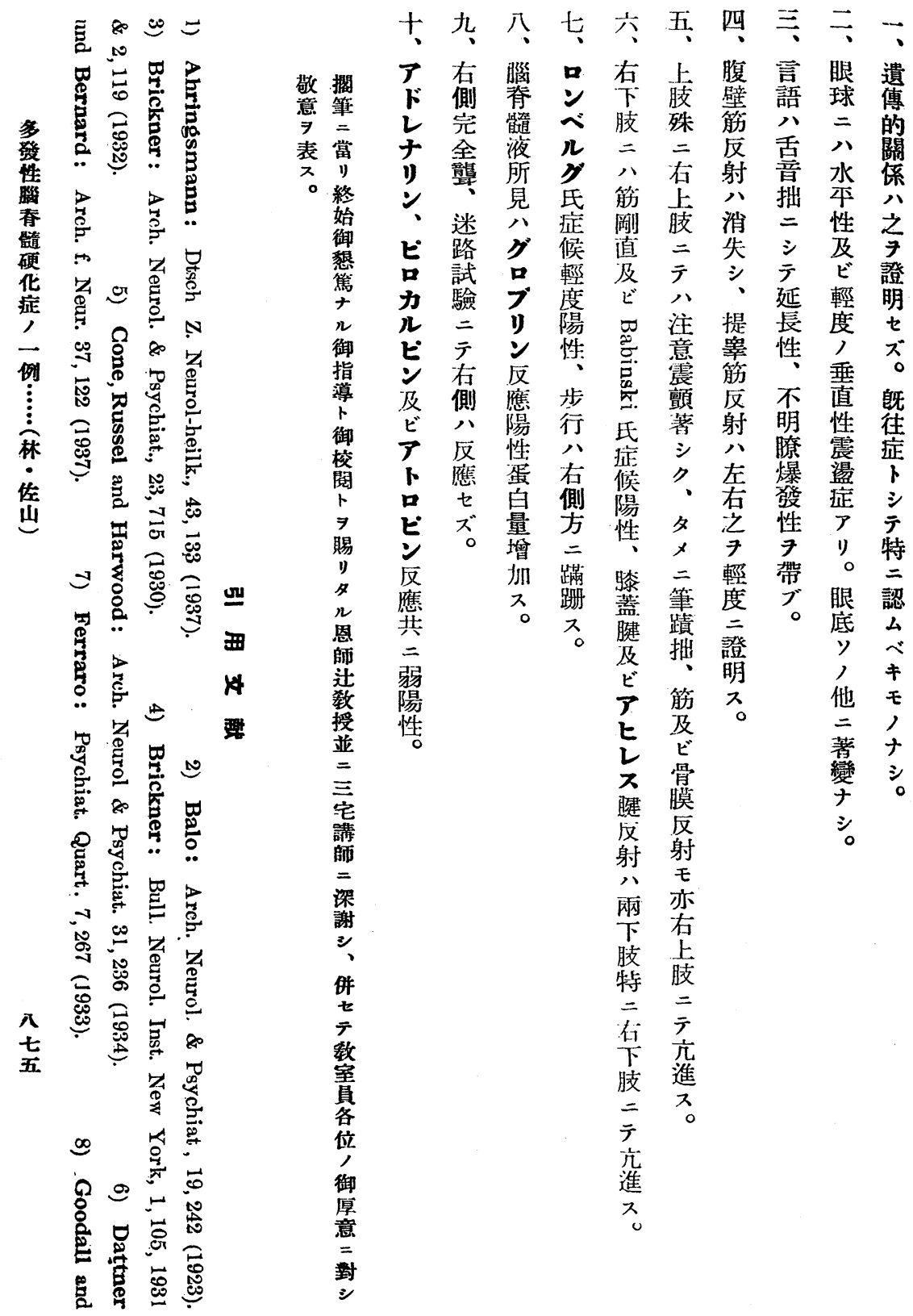




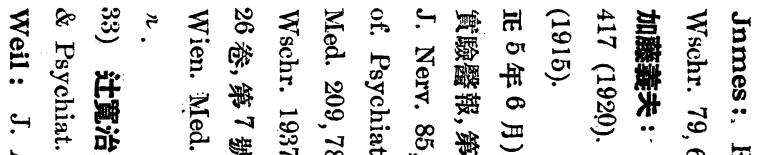

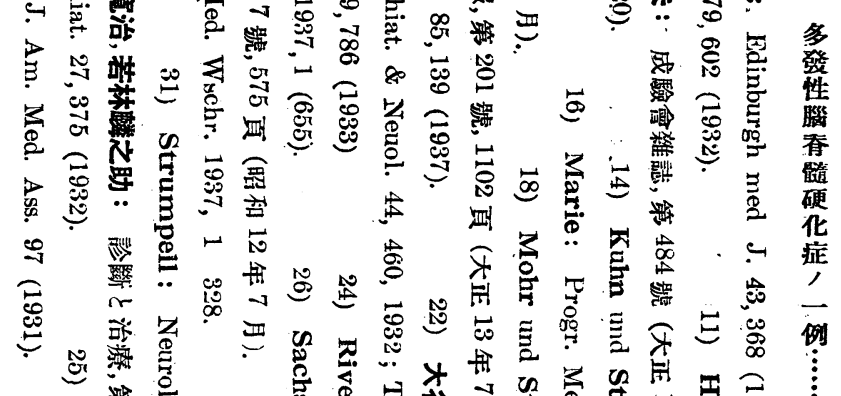

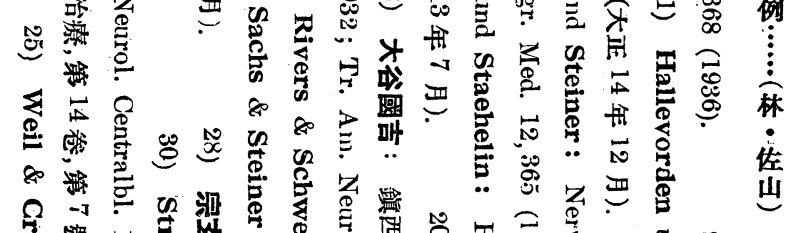

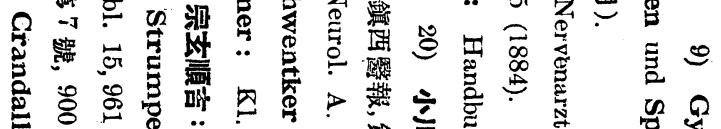

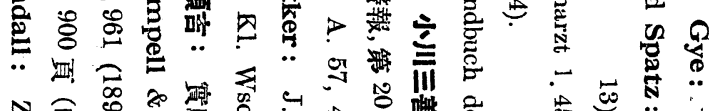

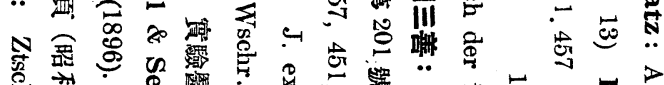

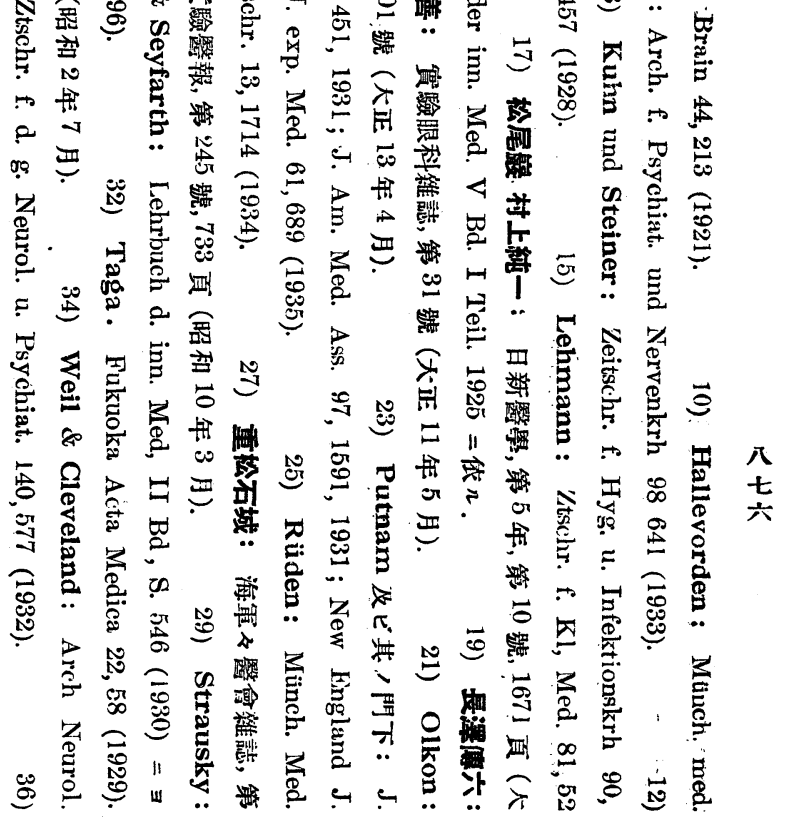




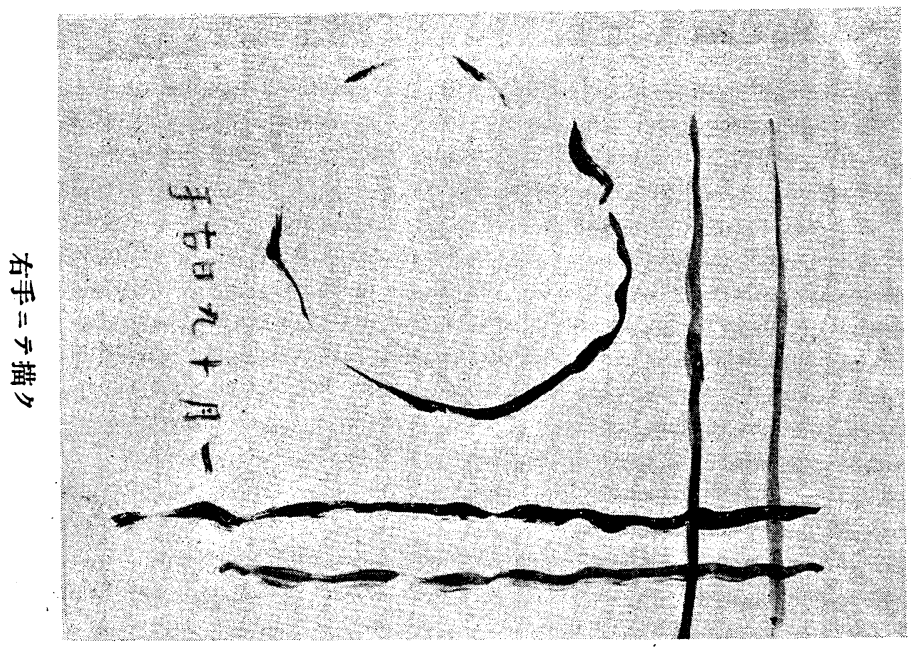

覃

\section{I}

婀

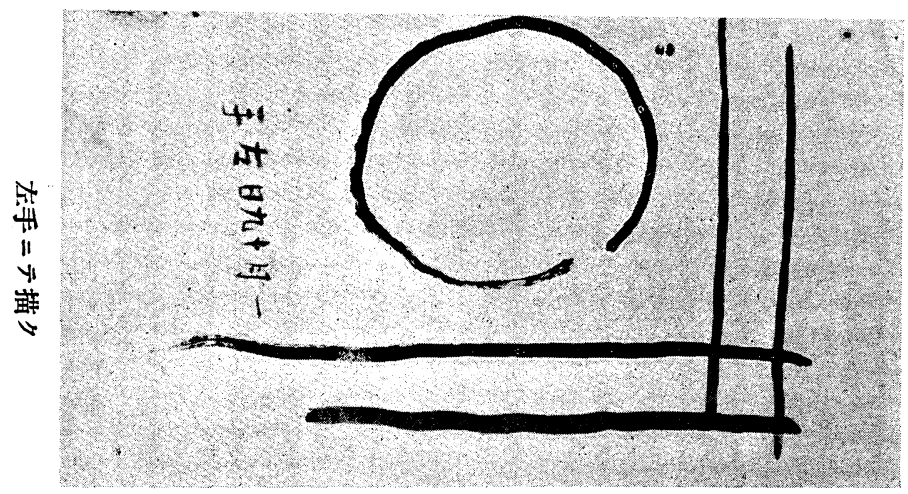

*

酷

E

路 融

$11 x$

国

똪

国玨

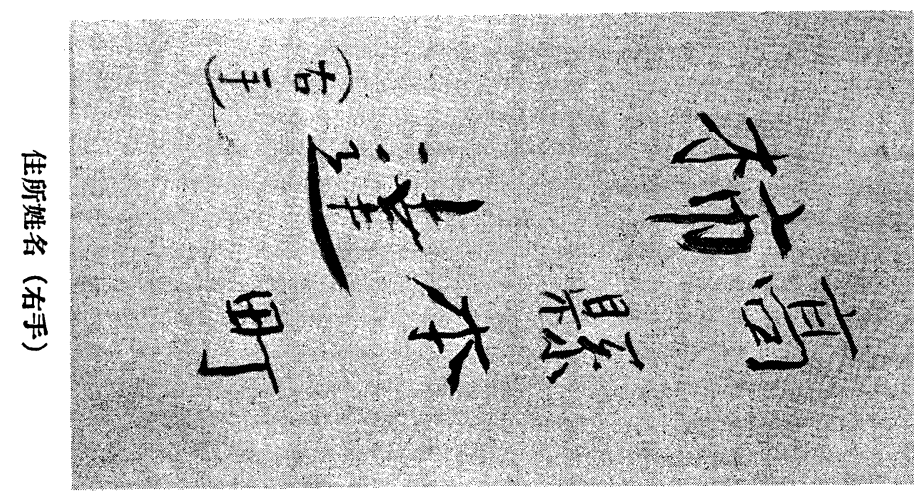

踏

III

践 


\title{
Über einen Fall von multipler Sklerose.
}

\author{
Von
}

\author{
Dr. H. Hayashi und Dr. S. Sayama.
}

(Aus der 1. Med. Klinik der Kaiserl. Universität zu Kyoto ị Japan. Direktor: Prof. Dr. K. Tsuji)

Die Verfasser hatten Gelegenheit, einen Kranken mit. multipler Sklerose zu beobachten. Es handelte sich um einen 30 jährigen Kaufmann. Subjektiv klagte der Patient über Gang- und Sprachstörung und Intentionszittern.

Weder in den hereditären Verhältnissen noch in den Auamnesen fand sich etwas, was man mit dem jetzigen Leiden in Zusammenhang hätte bringen können. Als Augensymtom zeigte der Patient einen heftigen horizontalen Nystagmus und zugleich einen leichten vertikalen Nystagmus. Am Augenhintergrund war nichts Pathologisches zu konstatieren. Die Sprache des Pat. war sehr undeutlich, am schlimmsten bei der Ausprache Zungenlaute, zugleich schleppend und skandierend.

Die Bauchdeckenreflexe waren erloschen, die beiden Cremasțerreflexe noch schwach auslösbar.

Das Intentionszittern war an beiden Oberextremitäten, besonders deutlich auf der rechten Seite, zu beobachten. Wegen des Intentinszitterns Schriftstörung. Biceps- und Tricepssehnenreflexe sowie auch der Periostalreflex waren alle gesteigert. An der rechten Unterextremität waren Rigidität der Muskeln und das Babinskische Zehenphänomen nachweisbar.

Der Patellar- und Achillessehnenreflex waren auf beiden Seiten, besonders deutlich rechts, gesteigert. Deutliches Rombergsches Symptom (Schwanken beim Stillstehen, besonders bei geschlossenen Augen). Beim Gehen Schwanken nach rechts.

An der Cerebrospinalflüssigkeit stark positive Globulinreaktion und Zunahme des Eiweissgehaltes, aber keine Drucksteigernng, Ausfall der Wassermannschen Reaktion negativ. 'Totale Taubheit des rechten 
Ohrs. Bei der Prüfung der Vestibularfunktion totaler Funktionsausfall des rechten Vestibularapparates. Bei der pharmakodynamischen Prüfung reagierte der Patient auf Adrenalin, Pilocarpin und Atropin etwas empfindlich.

Bei der Differentialdiagnose wurde auf Grund des normal gebliebenen Hirndrucks und des Fehlen sonstiger Tumorsymtome ein Kleinhirnbrückenwinkeltumor ausgeschlossen.

(Autoreferat) 